\title{
Effect of microwaving on different foods and biological systems
}

\author{
UPASANA, PARVEEN SHAISTA AND ARCHANA CHAKRAVARTY
}

Received: 25.09.2014; Accepted: 26.11.2014

See end of the paper for authors' affiliations

\section{UPASANA}

Department of Home Science (Food and Nutrition), Banaras Hindu University, VARANASI (U.P.) INDIA

Email: upasana87@gmail.com
ABSTRACT : The use of microwave cooking is tremendously increasing day by day as it is convenient, fast and economical. But, various evidences shows that microwaves destroy the nutrients of food, may create carcinogens in food, and unnecessary exposure to radiation can create several health issues. On the other hand, several studies reveal that if the consumer follows safety instructions carefully then microwave cooking may result in food with nutrient quality similar to those cooked by other cooking methods. Food safety is an important health issue, thus, there is a need to deal with the various aspects of microwaving. In this context, this review paper focuses on the effect of microwave cooking on different food items and biological systems.

KEY WORDS: Microwave cooking, Food safety, Health issue

口 HOW TO CITE THIS PAPER : Upasana, Shaista, Parveen and Chakravarty, Archana (2014). Effect of microwaving on different foods and biological systems. Asian J. Home Sci., 9 (2) : 650-654. 